\title{
Importance of early endoscopic and clinical evaluation of children with caustics ingestion
}

\author{
Enory Almanza-Miranda ${ }^{1}$, Gerardo Blanco-Rodríguez ${ }^{1}$, Jaime Penchyna-Grub ${ }^{1}$, Gustavo Teyssier-Morales ${ }^{1}$, \\ and Rubén Peña-Vélez ${ }^{2 *}$ \\ ${ }^{1}$ Servicio de Cirugía de Tórax y Endoscopia, Hospital Infantil de México Federico Gómez; ${ }^{2}$ Facultad de Medicina, Universidad Nacional Autónoma \\ de México. Mexico City, Mexico
}

\begin{abstract}
Background: Accidental ingestion of caustics in pediatrics continues to be a frequent problem that can lead to severe injuries and permanent sequelae that require esophageal rehabilitation programs. This study aimed to describe the medical care experience of children who ingested caustic substances in a tertiary hospital in Mexico City. Methods: We conducted a descriptive and analytical study. We described age, sex, type of caustics, clinical and endoscopic findings, and the radiological evolution of 284 patients who arrived during the acute phase. Results: The records of 336 children with a history of caustic ingestion were reviewed. The median age was 1.7 years, and the predominant sex was male. Caustic soda was the most accidentally ingested substance. We found an association between the severity of the esophageal injury with the presence of more than four symptoms at diagnosis $\left(\chi^{2}, p<0.001\right)$ and with the finding of oral lesions, sialorrhea, and vomiting $\left(\chi^{2}, p<0.05\right)$. Forty percent $(n=114)$ showed normal gastrointestinal endoscopy. Conclusions: In children with caustic ingestion, upper gastrointestinal endoscopy should be performed within 72 hours to evaluate the extent of the lesions. In this study, we found that more than four symptoms at admission, and oral lesions, sialorrhea, and vomiting are associated with the severity of the esophageal injury.
\end{abstract}

Keywords: Caustics. Esophagitis. Esophageal stenosis. Anthropyloric stenosis.

\section{Importancia de la evaluación clínica y endoscópica temprana de niños con ingesta de cáusticos}

\section{Resumen}

Introducción: La ingesta accidental de cáusticos continúa siendo un problema frecuente en pediatría que puede llegar a producir lesiones graves y secuelas permanentes que ameritarán programas de rehabilitación esofágica. El objetivo de este estudio es describir la experiencia en la atención médica de niños con ingesta de sustancias cáusticas en un hospital de tercer nivel en la Ciudad de México. Métodos: Se llevó a cabo un estudio descriptivo y analítico. Se describieron la edad, el sexo, el tipo de cáustico, los hallazgos clínicos y endoscópicos, así como la evolución radiológica, de 284 pacientes que llegaron en la fase aguda. Resultados: Se revisaron los expedientes de 336 niños con antecedente de ingesta de cáusticos. La mediana de edad fue de 1.7 años, con predominio del sexo masculino. La sosa cáustica fue la sustancia más ingerida

Correspondence:

*Rubén Peña Vélez

E-mail: rubenpevelez@ hotmail.com
Date of reception: $20-11-2020$

Date of acceptance: 03-05-2021

DOI: 10.24875/BMHIM.20000379
Available online: 16-12-2021 Bol Med Hosp Infant Mex. 2021;78(6):544-548

www.bmhim.com 1665-1146/@ 2021 Hospital Infantil de México Federico Gómez. Published by Permanyer. This is an open access article under the CC BY-NC-ND license (http://creativecommons.org/licenses/by-nc-nd/4.0/). 
y de tipo accidental. Encontramos asociación entre la gravedad de la lesión esofágica y la presencia de más de cuatro síntomas en el momento del diagnóstico $\left(\chi^{2}, p<0.001,\right)$, y con el hallazgo de lesiones orales, sialorrea y vómito $\left(\chi^{2}, p<0.05\right)$. El $40 \%$ de los niños ( $n=114$ ) tuvieron una endoscopia digestiva normal. Conclusiones: En los niños con ingesta de cáusticos debe realizarse una endoscopia digestiva alta en las primeras 72 horas para evaluar la extensión de las lesiones. En este estudio se encontró que tener más de cuatro síntomas al ingreso, así como la presencia de lesiones orales, sialorrea y vómito, se asocian con la gravedad de la lesión esofágica.

Palabras clave: Cáusticos. Esofagitis. Estenosis esofágica. Estenosis antropilórica.

\section{Introduction}

Ingestion of a caustic substance in pediatric patients is a frequently observed accident in emergency departments and poses a risk of potentially severe and irreversible injury to the upper gastrointestinal tract. This accidental or intentional ingestion represents a public health problem observed mainly in developing countries due to social, economic, and educational variables ${ }^{1,2}$. The highest incidence is observed in infants and preschoolers. It is accidental and occurs with substances found at home due to easy access to them because of their location. Additionally, these substances may be mislabeled or placed in inadequate containers ${ }^{3}$. The following have been identified as risk factors for intake: male gender, attention-deficit/hyperactivity disorder, lower educational level of parents, young maternal age, lack of supervision of children, and rural residence ${ }^{4}$.

Mortality is rare, but morbidity is devastating and, in some cases, lifelong, with short- and long-term complications, such as prolonged and multiple hospital admissions, esophageal or pyloric stenosis, as well as an increased risk of esophageal cancer in the long term ${ }^{5,6}$. This study aimed to present the experience of a tertiary pediatric hospital in the care of children with caustic substance ingestion.

\section{Methods}

We conducted a descriptive, analytical, retrospective study. We reviewed the biostatistical database of the Hospital Infantil de México Federico Gómez, a national referral center (Mexico City, Mexico). Clinical information was obtained from 336 pediatric patients (age $<18$ years) with a diagnosis of admission due to caustic ingestion between 1989 and 2009. We analyzed sociodemographic variables (age and sex), type of substance ingested, signs and symptoms (oral lesions, sialorrhea, vomiting, irritability, nausea, odynophagia, dysphonia, and dysphagia). We also registered those patients who underwent an initial endoscopic study (hospital admission $<72$ hours after ingestion) and a control esophagogram. The Zargar esophagitis classification ${ }^{7}$ was used to establish the degree of esophageal injury at initial endoscopy; in those where the gastric injury was documented, the Sakita-Miwa classification ${ }^{8}$ was used.

The endoscopic control study was performed in the third week after ingestion to define the finding of esophageal or pyloric stenosis. In addition, those children admitted 72 hours after ingesting the caustic substance, in whom the initial endoscopy was not performed, were registered as late admission.

\section{Statistical analysis}

We used descriptive statistics with measures of central tendency. For categorical variables, $\chi^{2}$ and risk tests were performed. Statistical significance was established with a $p$-value $<0.05$.

\section{Results}

We included 336 patients with a median age of 1.7 years (range: 6 months to 15 years) at the time of hospital admission; $57 \%$ were male. Most patients were admitted to the hospital for accidental ingestion; only three adolescents were admitted for attempted suicide. Alkali ingestion predominated, with $81.5 \%(n=274)$ of patients. Caustic liquid soda was the main substance ingested among other substances (Table 1).

After ingestion, 116 children (34.5\%) received some liquid or medication intended to neutralize the caustic administered by parents or first contact medical personnel. Gastric lavage was performed in 14 cases (4\%). The main clinical examination finding was oral lesions in 222 children (80\%). The most frequently observed signs and symptoms are described in Table 2.

Of the 336 patients, 52 were referred late, so they did not undergo endoscopy but only esophagogram in search of complications. In the 284 children who underwent endoscopic evaluation within 72 hours after ingestion, no esophageal lesions were observed in $40 \%$ of the patients $(n=114)$. In turn, esophageal lesions compatible 
Table 1. Type of ingested caustic substances and initial endoscopic findings in the esophagus and stomach

\begin{tabular}{|c|c|c|c|c|c|c|c|}
\hline & n (\%) & \multicolumn{5}{|c|}{ Grade of esophagitis according to Zargar } & Gastric lesion \\
\hline Ingested substance & & 0 & 1 & $2 \mathrm{~A}$ & $2 B$ & 3 & \\
\hline Liquid soda & $210(62.5)$ & 54 & 24 & 34 & 35 & 20 & 44 \\
\hline Solid soda & $25(7.5)$ & 12 & 1 & 4 & 3 & & 3 \\
\hline Soda gel & $24(7.1)$ & 9 & 5 & 6 & 3 & 1 & \\
\hline Chlorine & $14(4.1)$ & 10 & 3 & 1 & & & 2 \\
\hline Hydrochloric acid & $13(3.8)$ & 5 & 1 & 3 & 1 & 2 & 3 \\
\hline Salicylic acid & $12(3.6)$ & 3 & 2 & 4 & 3 & & 1 \\
\hline Ammonia & $10(3)$ & 5 & 2 & 3 & & & 3 \\
\hline Dishwasher & $3(0.9)$ & 3 & & & & & \\
\hline Floor cleaner & $3(0.9)$ & 3 & & & & & \\
\hline Podophyllin & $2(0.6)$ & & 1 & & 1 & & \\
\hline Disinfectants & $2(0.6)$ & 2 & & & & & \\
\hline Alkaline battery fluid & $2(0.3)$ & 1 & & & & & \\
\hline Merthiolate & $1(0.3)$ & & 1 & & & & 1 \\
\hline Calcium hydroxide & $1(0.3)$ & 1 & & & & & \\
\hline Thinner & $1(0.3)$ & 1 & & & & & \\
\hline Formaldehyde & $1(0.3)$ & 1 & & & & & \\
\hline Styrene monoxide & $1(0.3)$ & & 1 & & & & 1 \\
\hline Potassium permanganate & $1(0.3)$ & & & 1 & & & 1 \\
\hline Not identified & $10(3)$ & 4 & & & 2 & 2 & 2 \\
\hline Total & 284 & 114 & 41 & 56 & 48 & 25 & 61 \\
\hline
\end{tabular}

with grade 1 Zargar esophagitis were observed in $14 \%$ $(n=41)$; grade $2 A$ in $20 \%(n=56)$; grade $2 B$ in $17 \%$ $(n=48)$ and grade 3 in $9 \%(n=25)$. Regarding gastric injury, $79 \%(n=223)$ presented normal results, while gastric lesions were found in $21 \%$ of the cases, of which $70 \%(n=43)$ were classified as Sakita-Miwa A1 and 30\% $(n=18)$ as Sakita-Miwa A2 ulcers. There were no complications associated with the endoscopic procedure.

A significant association $(p<0.001)$ was identified between the presence of more than four symptoms at diagnosis (Table 2) with severe esophageal injury (Zargar 2B and 3). Oral lesions, sialorrhea, and vomiting indicated a risk for developing Zargar esophagitis $2 \mathrm{~B}$ and 3 . However, we should consider that most patients had concomitant symptoms. No severe degree of burning was documented in asymptomatic patients.

After treatment with antibiotics, corticosteroids, antisecretory agents, and enteral tube feeding, an esophagogram was performed to look for complications in the third week after ingestion. If stenosis was found, upper gastrointestinal endoscopy was performed to pass an endless string and subsequently perform dilatations with Tucker bougies. Esophageal stricture was documented in $21 \%$ of patients with Zargar $2 \mathrm{~A}$ lesion ( $n=12), 75 \%$ of patients with Zargar $2 B(n=36)$, and $88 \%$ of patients with Zargar 3 lesion $(n=22)$.

One patient with a history of ammonia ingestion and grade 2B Zargar esophagitis and three patients with caustic soda ingestion and grade 3 Zargar esophagitis developed pyloric stenosis (Table 3 ).

\section{Discussion}

Accidental ingestion of caustic substances and foreign bodies continues to be a critical medical-social health problem ${ }^{9}$. This study describes the clinical and 
Table 2. Signs and symptoms observed on admission to the emergency department in children with caustic ingestion and odds ratios for developing Zargar esophagitis $2 \mathrm{~B}$ and 3

\begin{tabular}{|l|c|c|c|c|}
\hline $\begin{array}{l}\text { Sign or } \\
\text { symptom }\end{array}$ & $\mathbf{n}(\%)$ & Odds ratio & $95 \% \mathbf{C I}$ & $\boldsymbol{p}$-values \\
\hline Oral lesions & $222(80)$ & 9.05 & $2.74-29.89$ & $<0.001$ \\
\hline Sialorrhea & $207(74)$ & 4.42 & $2.14-9.09$ & $<0.001$ \\
\hline Vomiting & $152(54)$ & 2.47 & $1.40-4.37$ & 0.001 \\
\hline Irritability & $70(25)$ & 1.70 & $0.95-3.01$ & 0.071 \\
\hline Nausea & $51(18)$ & 1.52 & $0.79-2.93$ & 0.201 \\
\hline Odynophagia & $47(17)$ & 1.63 & $0.83-3.19$ & 0.152 \\
\hline Dysphonia & $6(2)$ & 2.97 & $0.58-15.06$ & 0.169 \\
\hline Dysphagia & $5(1.8)$ & 4.47 & $0.73-27.35$ & 0.077 \\
\hline
\end{tabular}

$\mathrm{Cl}$, confidence interval.

Table 3. Initial endoscopic findings in 284 patients and percentage of esophageal stricture and pyloric stenosis development

\begin{tabular}{|l|c|c|c|}
\hline $\begin{array}{l}\text { Zargar } \\
\text { grade }\end{array}$ & $\begin{array}{c}\text { Initial endoscopy } \\
\mathbf{n}(\%)\end{array}$ & $\begin{array}{c}\text { Esophageal stricture } \\
\mathbf{n}(\%)\end{array}$ & $\begin{array}{c}\text { Pyloric } \\
\text { stenosis } \\
\mathbf{n}(\%)\end{array}$ \\
\hline 0 & $114(40)$ & 0 & 0 \\
\hline 1 & $41(14)$ & 0 & 0 \\
\hline $2 A$ & $56(20)$ & $12(21)$ & 0 \\
\hline $2 B$ & $48(17)$ & $36(75)$ & $1(2)$ \\
\hline 3 & $25(9)$ & $22(88)$ & $3(10)$ \\
\hline Total & 284 & 70 & 4 \\
\hline
\end{tabular}

endoscopic characteristics and evolution of pediatric patients with caustic ingestion. It has been reported that most ingestions occur in children $<5$ years of age 4 . In Mexico, a previous study reported a mean age of 3.2 years and male predominance ${ }^{10}$. A meta-analysis that included more than 8,000 children reported that the most frequent age was 2 years ${ }^{11}$. We observed a mean age of 1.7 years, with a male-to-female ratio of 1.3:1. As previously reported, the vast majority of these ingestions occurred accidentally due to children's curiosity or attempt to obtain food, whereas, in adolescents, it occurs intentionally. In this study, intentional ingestion was documented in $<1 \%$ of cases.

After ingesting a caustic substance, the initial clinical manifestations are diverse: vomiting, dysphagia, sialorrhea, abdominal pain, and hematemesis ${ }^{11,12}$. A multicenter observational study involving 162 children reported that the number of symptoms allowed physicians to predict the presence of severe esophageal injury ${ }^{13}$. The most useful clinical signs and symptoms to predict the presence of esophageal injury are vomiting, dysphagia, abdominal pain, and the presence of lesions in the oral cavity. If two or more of these signs and symptoms are present, the probability of finding esophageal lesions is higher, with a positive predictive value (PPV) of $43 \%$ and a negative predictive value (NPV) of $96 \%^{14}$. However, as a single finding, oral lesions have shown a PPV of only $31 \%$ and a relatively low NPV of $79 \%$ for detecting esophageal lesions ${ }^{15}$. Our study found an association between four or more of the symptoms listed in Table 2, the presence of oral lesions and esophageal lesions Zargar 2B and 3 , which should be considered when evaluating children with caustic ingestion. Also, we found that if children were asymptomatic, they did not have severe esophageal lesions; only a small proportion of children without oral lesions $(n=3)$ had severe esophageal lesions. These findings differ from the series published by Temiz et al. ${ }^{16}$, who reported that $12-26 \%$ of asymptomatic children show severe lesions on endoscopic evaluation. Therefore, it is recommended to perform upper endoscopy in patients with a history of caustic ingestion, even if they are asymptomatic ${ }^{1,16}$.

The ideal time to perform endoscopic evaluation after ingestion of caustic substances in children remains controversial ${ }^{17}$. Most studies recommend that it be performed in the first 24 to 48 hours after ingestion to assess the extent of the lesions and their severity, establish the prognosis, and guide treatment ${ }^{13,18}$. Endoscopy is not recommended more than four days after ingestion, as it increases the risk of esophageal perforation ${ }^{19}$. Currently, the Ibero-Latin American Clinical Practice Guide (Guía de Práctica Clínica IberoLatinoamericana) on caustic esophagitis in pediatrics recommends performing this study in the first 24 to 48 hours ${ }^{1,16}$. Endoscopic evaluation is performed during the first 72 hours in the Endoscopy Service of the Hospital Infantil de México Federico Gómez. In this study, the percentage of stenosis was similar to that published by Zargar et al. and other series ${ }^{19,20}$ : for grade $2 \mathrm{~A}$ lesions, $21 \%$ vs. $<15 \%$; for grade $2 \mathrm{~B}$ lesions, $75 \%$ vs. $70-90 \%$; and for grade 3 lesions, $88 \%$ vs. $83-100 \%$, respectively, in patients in whom endoscopy was performed in the first 72 hours. All late referral patients already had an esophageal stricture. 
In conclusion, the morbidity caused by caustic ingestion indicates that it is necessary to develop more effective prevention measures to avoid this type of accident. Furthermore, any patient with a history of ingestion of a caustic substance, even without symptoms, should undergo an endoscopic procedure within the first 24 to 72 hours since it is not possible to rule out some injuries. If the patient presents with more than four signs/ symptoms, or oral lesions, sialorrhea, or vomiting, severe esophageal damage should be suspected.

\section{Ethical disclosures}

Protection of human and animal subjects. The authors declare that no experiments were performed on humans or animals for this study.

Confidentiality of data. The authors declare that they have followed the protocols of their work center on the publication of patient data.

Right to privacy and informed consent. The authors have obtained the written informed consent of the patients or subjects mentioned in the article. The corresponding author has this document.

\section{Conflicts of interest}

The authors declare no conflict of interest.

\section{Funding}

None.

\section{References}

1. Pierre R, Neri S, Contreras M, Vázquez R, Ramírez LC, Riveros JP, et al. [lbero-latinamerican clinical practical guidelines on pediatric caustic esophagitis: physiopathology and clinical-endoscopic diagnosis ( $1^{\text {st }}$ part)]. Rev Chil Pediatr. 2020;91:149-57.
2. Rodríguez Guerineau L, Martínez Sánchez L, Quintillá Martínez JM, Trenchs Sainz De La Maza V, Vila Miravet V, Luaces Cubells C. Ingesta de cáusticos: situación actual y puesta al día de las recomendaciones. An Pediatr. 2011;75:334-40.

3. Riffat $F$, Cheng A. Pediatric caustic ingestion: 50 consecutive cases and a review of the literature. Dis Esophagus. 2009;22:89-94.

4. Arnold M, Numanoglu A. Caustic ingestion in children-a review. Semin Pediatr Surg. 2017;26:95-104.

5. Karaman I, Koç O, Karaman A, Erdoğan D, Çavusoglu YH, Afşarlar ÇE, et al. Evaluation of 968 children with corrosive substance ingestion. Indian J Crit Care Med. 2015;19:714-8.

6. Turner A, Robinson P. Respiratory and gastrointestinal complications of caustic ingestion in children. Emerg Med J. 2005;22:359-61.

7. Zargar SA, Kochhar R, Nagi B, Mehta S, Mehta SK. Ingestion of corrosive acids. Spectrum of injury to upper gastrointestinal tract and natural history. Gastroenterology. 1989;97:702-7.

8. Miyake T, Suzaki T, Oishi M. Correlation of gastric ulcer healing features by endoscopy, stereoscopic microscopy, and histology, and a reclassification of the epithelial regenerative process. Dig Dis Sci. 1980;25: 8-14.

9. Blanco-Rodríguez G, Teyssier-Morales G, Penchyna-Grub J, Madriñan-Rivas JE, Rivas-Rivera IA, Trujillo-Ponce de León A, et al. Characteristics and outcomes of foreign body ingestion in children. Arch Argent Pediatr. 2018;116:256-61.

10. Sánchez-Ramírez CA, Larrosa-Haro A, Vásquez-Garibay EM, Macías-Rosales $\mathrm{R}$. Socio-demographic factors associated with caustic substance ingestion in children and adolescents. Int $\mathrm{J}$ Pediatr Otorhinolaryngol. 2012;76:253-6.

11. Rafeey M, Ghojazadeh M, Sheikhi S, Vahedi L. Caustic ingestion in children: a systematic review and meta-analysis. J Caring Sci. 2016;5: 251-65.

12. Losada MM, Rubio MM, Blanca GJA, Pérez AC. Ingesta de cáusticos en niños, experiencia de 3 años. Rev Chil Pediatr. 2015;86:189-93.

13. Betalli P, Falchetti D, Giuliani S, Pane A, Dall'Oglio L, de' Angelis GL, et al. Caustic ingestion in children: is endoscopy always indicated? The results of an Italian multicenter observational study. Gastrointest Endosc. 2008;68:434-9.

14. Salzman M, O'Malley RN. Updates on the evaluation and management of caustic exposures. Emerg Med Clin North Am. 2007;25:459-76.

15. Gorman RL, Khin-Maung-Gyi MT, Klein-Schwartz W, Oderda GM, Benson B, Litovitz T, et al. Initial symptoms as predictors of esophageal injury in alkaline corrosive ingestions. Am J Emerg Med. 1992;10:189-94.

16. Pierre R, Neri S, Contreras M, Vázquez R, Ramírez LC, Riveros JP, et al. Guía de Práctica Clínica Ibero-Latinoamericana sobre la Esofagitis Cáustica en Pediatría: aspectos terapéuticos ( $2^{\mathrm{a}}$ parte). Rev Chil Pediatr. 2020;91:289-99.

17. Millar AJ, Cox SG. Caustic injury of the oesophagus. Pediatr Surg Int. 2015;31:111-21.

18. Ripoll Trujillo N, Martínez Sánchez L, Habimana Jordana A, Trenchs Sainz de La Maza V, Vila Miravet V, Luaces Cubells C. Ingesta de cáusticos: análisis de la seguridad y beneficio de un protocolo menos agresivo. An Pediatr. 2019;90:207-12

19. Zargar SA, Kochhar R, Mehta S, Mehta SK. The role of fiberoptic endoscopy in the management of corrosive ingestion and modified endoscopic classification of burns. Gastrointest Endosc. 1991;37:165-9.

20. Araya R, Montoro M, Estay R, Espinosa N. Clasificaciones en Gastroenterología. Clasificación de Zargar: Ingestión de cáusticos. Gastroenterol Latinoam. 2016;27:126-9. 